\title{
Leaf enclosure measurements for determining volatile organic compound emission capacity from Cannabis spp.
}

\author{
Chi-Tsan Wang ${ }^{\mathrm{a}}$, Christine Wiedinmyer ${ }^{\mathrm{b}}$, Kirsti Ashworth ${ }^{\mathrm{c}}$, Peter C. Harley ${ }^{\mathrm{d}}$, John Ortega ${ }^{\mathrm{d}}$, \\ William Vizuete ${ }^{\text {a,* }}$
}

a Department of Environmental Sciences \& Engineering, University of North Carolina, Chapel Hill, NC, USA

${ }^{\mathrm{b}}$ Cooperative Institute for Research in Environmental Sciences, University of Colorado Boulder, Boulder, CO, USA

c Lancaster Environment Centre, Lancaster University, UK

${ }^{\mathrm{d}}$ Denver, Colorado, USA

\section{A R T I C L E I N F O}

Keywords:

Cannabis spp.

Leaf enclosure

Emission capacity

Biogenic volatile organic compound

Particulate matter

Ozone

\begin{abstract}
A B S T R A C T
The legal commercialization of Cannabis for recreational and medical use in certain US states has effectively created a new and nearly unregulated cultivation industry. Within the city limits of Denver, Colorado, there are now more than 600 registered Cannabis spp. cultivation facilities (CCFs) for recreational and medical uses, each containing thousands of plants. Ambient measurements collected inside growing operations pre-legalization have found concentrations as high as $50-100 \mathrm{ppbv}$ of terpenes; a group of highly reactive biogenic volatile organic compounds (BVOCs) and known precursors for the formation of ozone and particulate matter (PM). Due to its illicit nature there has been insufficient experimental data produced to determine Cannabis spp. emission rates. This study used, for the first time, an enclosure chamber and live Cannabis spp. plants during a 90-day growing period consisting of four different strains of Cannabis spp.: Critical Mass, Lemon Wheel, Elephant Purple, and Rockstar Kush. These measurements enabled characterization of terpenes and estimates of emission capacity (EC, $\mu \mathrm{gC} \mathrm{g}^{-1} \mathrm{hr}^{-1}$ ) at standard conditions. During peak growth, the percentages of individual BVOC emissions were dominated by $\beta$-myrcene (18-60\%), eucalyptol (17-38\%), and d-limonene (3-10\%) for all strains. Our results showed large variability in the rate and composition of terpene emissions across different strains. For the Critical Mass and Lemon Wheel, the dominant terpenoid was eucalyptol (32\% and 38\%), and it was $\beta$-myrcene (60\% and 45\%) for the Elephant Purple and Rockstar Kush. Critical Mass produced the highest terpene emission capacity $\left(8.7 \mu \mathrm{gC} \mathrm{g}^{-1} \mathrm{hr}^{-1}\right)$ and Rockstar Kush the lowest $\left(4.9 \mu g \mathrm{~g} \mathrm{~g}^{-1} \mathrm{hr}^{-1}\right)$. With $600 \mathrm{CCFs}$ in Denver, and assuming 10,000 plants per CCF, an emission capacity of $8.7 \mu \mathrm{gC} \mathrm{g}^{-1} \mathrm{hr}^{-1}$ would more than double the existing rate of BVOC emissions to 520 metric ton year ${ }^{-1}$. Using Maximum Incremental Reactivity (MIR) values the total

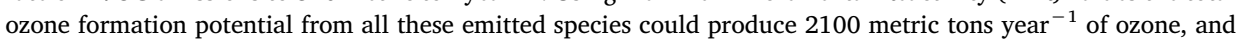
based on published secondary organic aerosols yields 131 metric tons year ${ }^{-1}$ of PM. It is likely that the ECs calculated here are lower than those achieved in CCFs where growing conditions are optimized for rapid growth and higher biomass yields. Further studies including a greater number of the 620 available Cannabis spp. strains and a wider range of treatments are needed to generate a representative dataset. Such a dataset could then better enable assessments of the potential impacts of this new industry on indoor and regional air quality.
\end{abstract}

\section{Introduction}

The use of Cannabis spp. and its various products have long been controversial, with opponents of the relaxation of restrictions pointing to studies linking long-term use to mental health problems (WHO, 2016), and advocates arguing that it provides many therapeutic benefits (Ashton, 2001; Madras and World Health Organisation, 2015). Supporters of the decriminalization and legalization of Cannabis spp. liken current regulations to the early 20th Century United States prohibition laws, suggesting that many of the detrimental societal impacts of Cannabis spp. production, sale, and use are directly associated with its illegality. This argument is beginning to hold sway and, for the first time, in 2014, the United Nation Global Commission on Drug Policy (UNGCDP) called for legalization with regulation (UNGCDP, 2014). The UN Office on Drugs and Crime reports over 180 million users worldwide (UNODC, 2016), and the cultivation and use of Cannabis spp. for

\footnotetext{
* Corresponding author.

E-mail address: vizuete@unc.edu (W. Vizuete).
} 
medical purposes is already legal or decriminalized in more than 40 countries around the world. The UNGCDP argues that regulation of the recreational use of Cannabis spp. would bring transparency at all stages of the supply chain, reducing associated criminal activity and trafficking, ensuring drug safety and allowing monitoring of environmental impacts. Furthermore, legalization of the recreational use of Cannabis spp. offers an opportunity for increased fiscal revenue: in the US state of Colorado, tax revenue from sales of Cannabis spp. for recreational use in 2014 (the first year of legal commercial sales) amounted to over $\$ 76$ million (UNODC, 2016). Many US states have followed Colorado's lead, a trend that is expected to spread to many countries around the world.

Cannabis spp. are native to the Indian sub-continent and require warm temperatures and high light intensity to achieve good yields. Optimal growing conditions for commercial varieties are typically around $30^{\circ} \mathrm{C}, 1000-1500 \mu \mathrm{mol} \mathrm{m}^{-2} \mathrm{~s}^{-1}$ of photosynthetically active radiation (PAR; depending on growth stage) and, in an outdoor environment, 22.7 L of water per day per plant (Green, 2009; Mills, 2012; Bauer et al., 2015). Although Cannabis spp. can be grown outdoors in many regions of the world, all large-scale commercial cultivation in Denver, Colorado occurs indoors or in greenhouses. This enables yearround operations, ensures security, and allows for the precise control of the growing environment to maximize yields. At indoor commercial facilities, such as those found in Denver, plants receive light $24 \mathrm{~h}$ per day during the initial growth stages. Since Cannabis spp. are photoperiod sensitive (i.e. only flowering when the length of daylight shortens), once sufficient leafy biomass accumulation has occurred, the lighting regime in these facilities is altered to induce budding. In most cases, a 12-h on, 12-h off pattern is used, but this can vary to as little as $8 \mathrm{~h}$ on over a 24 -h period. Typically, the flower buds are enriched in the active ingredients Tetrahydrocannabinol (THC) and Cannabidiol (CBD) in comparison to foliage, and in most varieties, other plant tissues (stems, branches, roots) contain negligible amounts of these compounds. The average yield of saleable biomass from commercial strains of Cannabis spp. is around $1 \mathrm{~kg}$ per plant (Green, 2009; Jankauskiene and Gruzdeviene, 2015), and the approximate time to harvest is 2-3 months, permitting $\sim 5$ crop cycles per year (Green, 2009).

The production of Cannabis spp. in indoor facilities has been the focus of studies quantifying the environmental impacts of energy and water use (Mills, 2012). Considerably less is known about the potential impacts of this industry on indoor and outdoor air quality due to BVOCs emitted directly from the plants themselves. Cannabis spp. plant tissues, such as leaves and buds, are known to contain many BVOCs. Previous studies of dried plant material (Turner et al., 1980; Rice and Koziel, 2015) and oil extracts from buds (Ross and ElSohly, 1996) have identified high concentrations of monoterpenes $\left(\mathrm{C}_{10} \mathrm{H}_{16}\right)$, other terpenoid compounds (e.g. eucalyptol; $\mathrm{C}_{10} \mathrm{H}_{18} \mathrm{O}$ ), sesquiterpenes $\left(\mathrm{C}_{15} \mathrm{H}_{24}\right)$, and methanol that is associated with plant growth and cell expansion. Other studies have focused on identifying characteristic odor profiles to facilitate detection of illicit Cannabis spp. products or chromatographic signatures to detect smuggled drugs (Hillig, 2004; Fischedick et al., 2010; Rice and Koziel, 2015). Measurements of BVOC concentrations in headspace and (illicit) grow rooms have detected and identified many hundreds of BVOCs, often in very low concentrations, of which monoand sesquiterpenes are dominant. These species include: $\alpha$-pinene, $\beta$ pinene, $\beta$-myrcene, limonene, hashishene, caryophyllene, and humulene (Martyny et al., 2013; Marchini et al., 2014). Hood et al. (Hood et al., 1973) analysed the air above Cannabis spp. plants and found that the monoterpenes $\alpha$-pinene, $\beta$-pinene, $\beta$-myrcene and d-limonene accounted for over $85 \%$ of the detected VOCs emitted, with acetone and methanol contributing a further $10 \%$. Marchini et al. (2014) reported the composition of headspace, but not the concentration of each species. Martyny et al. (2013) reported total monoterpene (consisting of $\alpha$ pinene, $\beta$-pinene, $\beta$-myrcene and $d$-limonene) concentrations of $50-100$ ppbv in the grow rooms of illicit cultivation facilities, suggesting high emissions from growing Cannabis spp.. Due to Cannabis spp. status as an illegal Schedule 1 drug by the U.S. Drug Enforcement
Agency (USD.E.A., 2017), there are no known systematic studies to characterize and specifically quantify the volatile emissions during the growing and budding process. Based on previous studies, however, the Cannabis spp. plants have the potential to emit VOCs into the facility in which they are grown, and also into the atmosphere.

Emissions of VOCs in urban areas have the potential to contribute to ozone production (Fehsenfeld et al., 1992; Pierce et al., 1998; Ryerson et al., 2001) and the formation of secondary organic aerosol (SOA) (Kanakidou et al., 2005; Lee et al., 2006). Once VOCs are released into the urban atmosphere, they can react with the hydroxyl $(\mathrm{OH})$ radical, nitrate $\left(\mathrm{NO}_{3}\right)$ radical, and ozone $\left(\mathrm{O}_{3}\right)$ (Hites and Turner, 2009; Braure et al., 2014). These initial oxidation reactions lead to further atmospheric processing, which can ultimately lead to the formation of ozone and SOA. In Denver, for example, where there are $>600$ Cannabis spp. cultivation facilities releasing BVOCs, the magnitude of these emissions has the potential to impact local and regional air quality, depending to some extent on the precise mix of compounds emitted. To understand the effect of BVOC emissions from these facilities on atmospheric chemistry and composition, it is necessary to identify and quantify the sources.

The goal of this study was to estimate the emission capacity (EC, $\mu \mathrm{gC} \mathrm{g}^{-1} \mathrm{hr}^{-1}$ ) range and terpene emission composition of cannabis plants. There is sparse BVOC data available from enclosure techniques, and thus these studies provide new data on the quantification of emissions of BVOCs from live commercially-available strains of Cannabis spp. at different phenological stages in their lifecycle.

\section{Methods}

Air samples were collected from Cannabis spp. using plant enclosures onto solid adsorbent cartridges. These cartridges were later analysed using gas chromatography with mass spectrometry and flame ionization detection (GC-MS/FID) to identify individual BVOC compounds and quantify emission rates. The plants were purchased by volunteers and were handled, housed, and sampled in a private off-site location. After the experiments, those plants were disposed of and composted locally. We did not have access to laboratory facilities or a growth room with a controlled environment. Thus, these experiments should be viewed as field measurements.

\subsection{Cultivation}

Four Cannabis spp. strains, commonly found in CCFs in Colorado, were studied: "Rockstar Kush" (RK), "Elephant Purple" (EP), "Lemon Wheel (LW)", and "Critical Mass" (CM). Twelve plants (3 from each strain) were grown under monitored conditions over a period of 14 weeks during the summer of 2016. The plants were bought on July 8, 2016 and transplanted to 1 US gallon (3.8 L) pots on July 15, 2016, at which time one additional pot (used as a control) was filled with identical soil. The soil used was a general use potting soil suitable for most plants. The plants were placed on trays and allowed to acclimate to the growing environment. The plants were kept well-irrigated with water being added to the trays every $2-3$ days. In a growing facility growing lights are kept on for $24 \mathrm{~h}$ a day. Thus, three $15 \mathrm{~W}$ LED growing lamps were positioned $1 \mathrm{~m}$ above the top of the pots and the growing plants received $500-900 \mu \mathrm{mol} \mathrm{m}^{-2} \mathrm{~s}^{-1}$ of light continuously for $24 \mathrm{~h}$ (dependent on the distances between the leaf and growth light). The temperature of the growth room was not controlled and ranged between 15 and $30^{\circ} \mathrm{C}$, which is typical for local ambient conditions during summer in Denver. All plants received the same treatment and were regularly rotated to minimize edge effects and to ensure, as much as possible, that all plants experienced the same light and temperature environment. 


\subsection{Plant enclosure sampling}

A standard plant enclosure sampling method was applied to measure BVOC emission rates (Tholl et al., 2006; Ortega and Helmig, 2008; Ortega et al., 2008). Air samples were collected from whole-plant enclosures for one specimen of each of the four strains and the blank pot after 12, 30, 46, and 96 days of growth since July 8, 2016. The same sampling routine was followed on each occasion. The pot containing the largest and tallest plant from each strain was selected and placed carefully in a 5 US gallon (19L) PFA Teflon pail liner (Welch Fluorocarbon, Dover, NH, USA). The plants were handled as gently as possible to minimize emissions due to disturbance (Ortega and Helmig, 2008; Ortega et al., 2008). Ambient air was pumped through Teflon tubing (25.4 mm O.D.), first through an activated charcoal filter to remove $\mathrm{O}_{3}$ and VOCs, and then into the enclosure system. This enclosure system was designed to act as a continuous stirred-tank reactor (CSTR) with a constant flow rate of $2.4-2.7 \mathrm{~L} \mathrm{~min}^{-1}$. A thermocouple was fed into the air space, and the bag was then clamped tightly around the pot until the bag inflated, indicating positive pressure within the enclosure. Since the measurements were done indoors, a $90 \mathrm{~W}$ growth lamp was positioned above the Teflon bag, delivering $650-900 \mu \mathrm{mol} \mathrm{m}^{-2} \mathrm{~s}^{-1}$ (PAR) at the plant top as measured by a quantum sensor (Li-COR model 190-R, Lincoln, Nebraska). Air flowed continuously through the enclosure for $30 \mathrm{~min}$ prior to sampling, allowing time for several exchanges of air and for the VOC concentrations to reach a steady-state. After $30 \mathrm{~min}$, BVOC sampling commenced. During sampling, two stainless steel adsorbent cartridges, each containing $\sim 400 \mathrm{mg}$ of Tenax TA and Carbograph 5TD in series (Markes International, Llantrisant, UK), were connected in parallel to the Teflon line exiting the enclosure. Air exiting the enclosure was pulled at a known flow rate (between 220 and $250 \mathrm{ml} \mathrm{min}^{-1}$ ) through each cartridge for $30 \mathrm{~min}$, resulting in a sample collection on each cartridge of between 6.5 and 7.5 L. Terpene concentrations measured in these samples therefore represented an average over that 30 -min collection period, during which time flow rate, irradiance, and air temperature were maintained at a relatively constant value.

Following sampling, each cartridge was securely capped at both ends and refrigerated prior to analysis. After 46 and 96 days of growth, the sampled plants were harvested and dried at room temperature for over one week. At the end of the drying time, leaves and buds were removed from each plant, and weighed to obtain the dry weight mass (Mdry (g)) for each strain. Of the original 12 plants, the 10 healthiest ones by visual inspection were chosen for sampling. The emission rates were therefore normalized using leaves from the plants that were weighed in the 46- and 96-day growth periods. Details of the leaf enclosure measurements are presented in Table 1 . In addition to the enclosure measurements of the four Cannabis spp. strains, air samples were taken from the pot containing only soil and from an otherwise empty enclosure bag to act as controls. For these controls, the soil was moistened, and the Teflon bag was placed around the pot in the same way that the plants were treated.

Enclosure carbon dioxide $\left(\mathrm{CO}_{2}\right)$ concentrations are important for the calculation of photosynthesis rates. Further, is important to keep $\mathrm{CO}_{2}$ concentrations similar to ambient conditions so that BVOC emission rates are not inadvertently affected. These measurements of $\mathrm{CO}_{2}$ concentrations, however, were not available during this study. In the study to keep concentrations similar to ambient we developed a protocol that set the input air flow rate of $2.4-2.7 \mathrm{~L} \mathrm{~min}^{-1}$ resulting in a high chamber air exchange rate of $8.2 \mathrm{hr}^{-1}$. Using this exchange rate we calculated the reduction in $\mathrm{CO} 2$ by assuming: photosynthesis rates of $10 \mu \mathrm{mol} \mathrm{m}{ }^{-2} \mathrm{~s}^{-1}$, ambient input $\mathrm{CO}_{2}$ concentration of $400 \mathrm{ppm}$, active leaf area of $0.015 \mathrm{~m}^{2}$ per plant. The estimated reduction in steady-state $\mathrm{CO}_{2}$ concentrations were approximately $300 \mathrm{ppm}$ or a reduction of $100 \mathrm{ppm}$. There amount of reduction is within the normal range of plant enclosure experiments. Therefore, we assume that this did not have an adverse impact on BVOC emission rates.

\subsection{Analysis method and instrument (GCMS \& GCFID)}

Samples were thermally desorbed from the cartridges and analysed using a Gas Chromatograph (GC) (Agilent Technologies, model 7890 A) coupled to both a flame ionization detector (FID) and a mass spectrometer (MS) (model 5975C), following published protocols (Harley et al., 2014). Thermal desorption (TD) was achieved by heating the adsorbent cartridges to $275^{\circ} \mathrm{C}$ in a UNITY TD (model UNITY, Markes International, Llantrisant, UK), followed by focusing the analyses on to a small cryotrap, and then heating this final trap as the analytes were injected on to the column. Helium was used as the carrier gas in the capillary column (RESTEK Rtx-5 model 10224, $30 \mathrm{~m}, 0.32 \mathrm{~mm}$, ID, $0.25 \mu \mathrm{m}$ film thickness). The GC oven temperature cycle started at $35^{\circ} \mathrm{C}$ and was held at that temperature for $1 \mathrm{~min}$, subsequently increasing $10{ }^{\circ} \mathrm{C}$ per minute up to $260{ }^{\circ} \mathrm{C}$ for each cartridge. The peak area associated with $m / z 93$, the dominant monoterpene ion fragment, of each terpenoid was quantified by GC-MS. To account for changes in MS sensitivity, $2 \mathrm{ml}$ of an internal standard, decahydronaphthalene (DHN), was sampled on to each adsorbent cartridge during the analysis. The measured terpenoid signals were normalized by dividing the $\mathrm{m} / \mathrm{z} 93$ mass fragment by the $m / z 95$ fragment of DHN. Additional calibrations were performed by loading sorbent tubes with 100 standard $\mathrm{cm}^{3}$ of a gas-phase standard containing $335 \mathrm{ppb}$ of isoprene and $215 \mathrm{ppb}$ of the monoterpene camphene. Two to four of these standard samples were run on the GC-MS and GC-FID for each batch of enclosure samples. The resulting signals were used to calculate a GC-FID response factor and a GC-MS sensitivity, which in turn were used to calculate gas-phase concentrations and emission rates.

The National Institute of Standards and Technology (NIST) database was used to identify individual monoterpenes from the GC-MS peaks by their mass fragmentation patterns using electron impact ionization. The

Table 1

Summary of leaf enclosure sampling conditions including flow rates, leaf area (when measured), and dry leaf weight.

\begin{tabular}{|c|c|c|c|c|c|c|c|c|}
\hline & Strain & $\begin{array}{l}\text { Air temp, in } \\
\text { enclosure }\left({ }^{\circ} \mathrm{C}\right)\end{array}$ & $\begin{array}{l}\text { PAR }(\mu \mathrm{mol} \\
\left.\mathrm{m}^{-2} \mathrm{~s}^{-1}\right)\end{array}$ & $\begin{array}{l}\text { Flow rate in (L } \\
\left.\min ^{-1}\right)\end{array}$ & $\begin{array}{l}\text { Sampling flow rate (L } \\
\left.\min ^{-1}\right)\end{array}$ & $\begin{array}{l}\text { Sampling time } \\
\text { (min) }\end{array}$ & $\begin{array}{l}\text { Estimated leaf area } \\
\left(\mathrm{m}^{2}\right)\end{array}$ & $\begin{array}{l}\text { Dry Leaf weight } \\
\text { (g) }\end{array}$ \\
\hline \multirow[t]{5}{*}{30 days growth } & Critical Mass & 23.9 & 650 & 2.37 & $0.24 \& 0.254$ & 30 & 0.015 & N/A \\
\hline & Lemon Wheel & 23.9 & 650 & 2.37 & $0.24 \& 0.254$ & 30 & 0.0093 & N/A \\
\hline & $\begin{array}{l}\text { Elephant } \\
\text { Purple }\end{array}$ & 23.4 & 650 & 2.37 & $0.24 \& 0.254$ & 30 & 0.0047 & N/A \\
\hline & Rockstar Kush & 22.5 & 650 & 2.37 & $0.24 \& 0.254$ & 30 & 0.0073 & N/A \\
\hline & Soil & 22 & 650 & 2.37 & $0.24 \& 0.254$ & 30 & N/A & N/A \\
\hline \multirow[t]{5}{*}{46 days growth } & Critical Mass & 27 & 900 & 2.7 & $0.253 \& 0.257$ & 30 & N/A & 0.985 \\
\hline & Lemon Wheel & 28 & 900 & 2.7 & $0.253 \& 0.257$ & 30 & N/A & 0.592 \\
\hline & $\begin{array}{l}\text { Elephant } \\
\text { Purple }\end{array}$ & 26 & 900 & 2.7 & $0.253 \& 0.257$ & 30 & N/A & N/A \\
\hline & Rockstar Kush & 26.5 & 900 & 2.7 & $0.253 \& 0.257$ & 30 & N/A & 0.444 \\
\hline & Soil & 26 & 900 & 2.7 & $0.253 \& 0.257$ & 30 & N/A & N/A \\
\hline
\end{tabular}




\section{A}

30 Days of Growth

Critical Mass $(1.4 \mu \mathrm{g} \mathrm{C} / \mathrm{hr})$
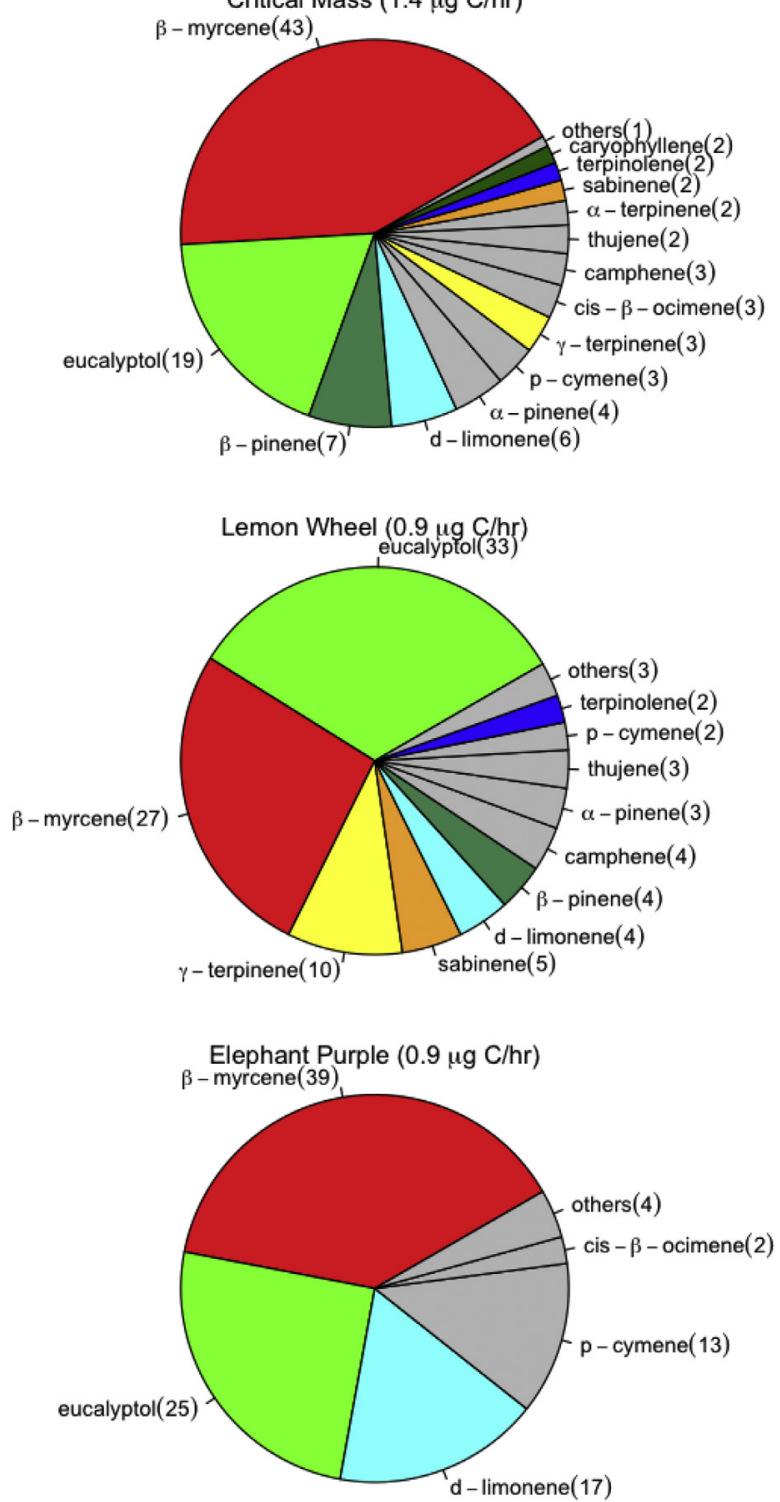

Rockstar Kush $(0.7 \mu \mathrm{g} \mathrm{C/hr})$

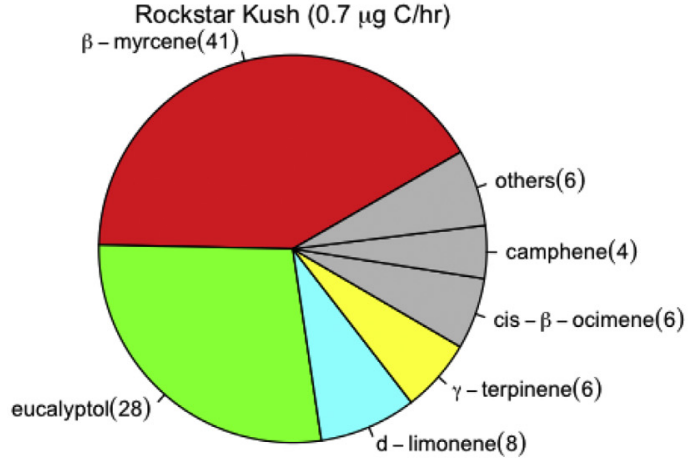

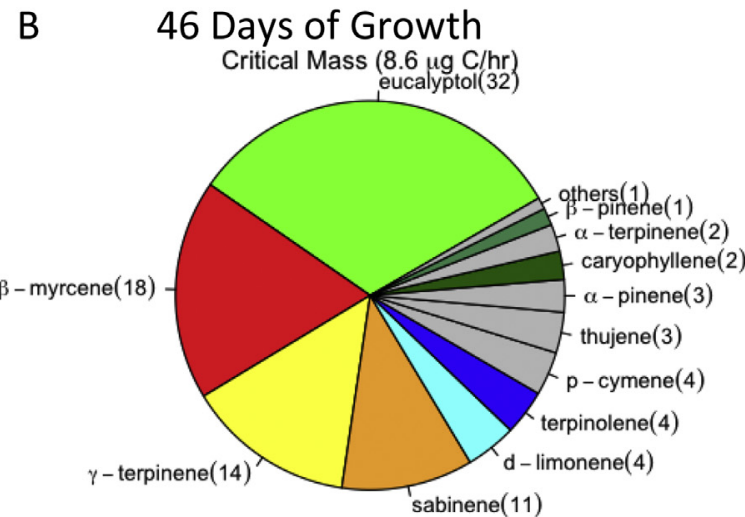

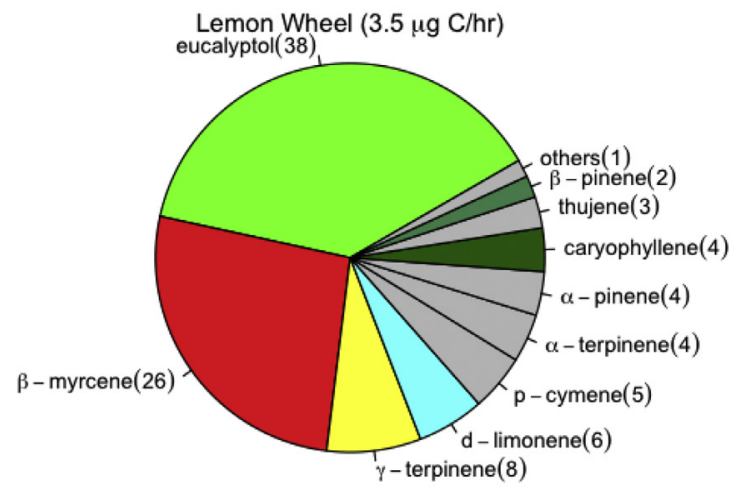

Elephant Purple $(4.5 \mu \mathrm{g} \mathrm{C/hr})$

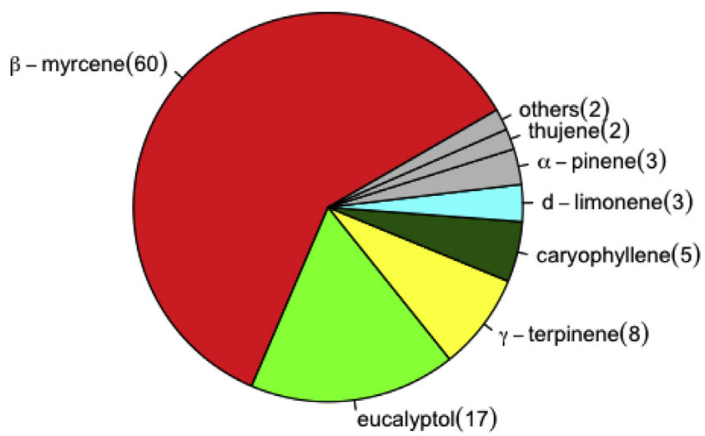

Rockstar Kush (2.2 $\mu \mathrm{g} \mathrm{C/hr)}$

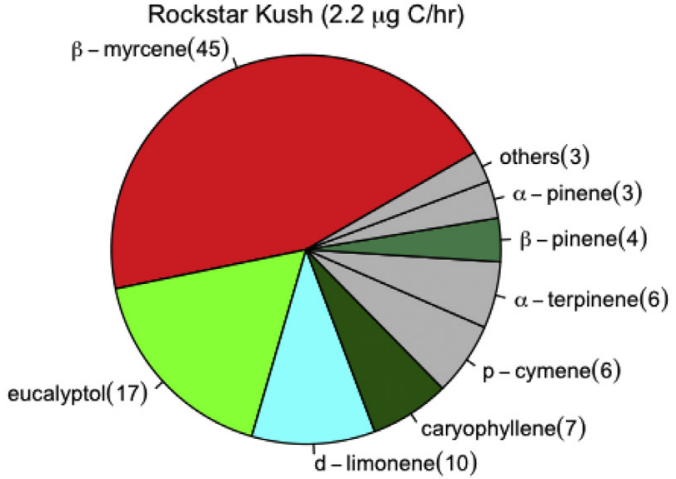

Fig. 1. Total terpene emission rate per plant $\left(\mu \mathrm{g} \mathrm{C} \mathrm{hr}^{-1}\right)$ and composition of emissions for (A) 30-day, and (B) 46-day growth periods from four strains of Cannabis spp.: Critical Mass, Lemon wheel, Elephant Purple, and Rockstar Kush. Numbers in parentheses represent the percentage of total emissions. (For interpretation of the references to colour in this figure legend, the reader is referred to the Web version of this article.) 
preliminary calculations of VOC concentrations based on GC-MS peak areas were cross-checked against the GC-FID. FID peaks of the DHN internal standard were used to ensure consistency and flag instrument drift. The measurement limitations of GC-FID and GC-MS are calculated using the blank sample. For the terpene compounds, the detection limits (DL) are three standard deviations of blank values. The average VOC concentrations from the two cartridges drawn from each enclosed plant, typically calculated by the GC-FID, was used due to its stability and linearity. In the case that there was a co-elution effect and the FID signal was lower than the FID detection limits, the GC-MS results were used. The DL of terpene by GC-MS is $0.004 \mu \mathrm{g} \mathrm{C} \mathrm{hr}{ }^{-1}$. If the results were lower than the limits a Non-Detection symbol (ND) is shown. All of the emission rate calculated from the FID and MS signal are included in the supplemental document as Table S1A and Table S1B. Other details about the analysis, such as retention time of each terpene species and fragment percentage of ion $\mathrm{m} / \mathrm{z} 93$ are also included in the supplemental document shown in Table S2.

\subsection{Calculation of emission capacity}

The EC and its algorithms were standardized in Guenther et al. (1993) and are based entirely on temperature and incident light energy. Our study follows these best practices, which have been applied to several studies (Funk et al., 2003; Ortega and Helmig, 2008; Ortega et al., 2008; Sakulyanontvittaya et al., 2008). While this is the standard practice in derivation of EC for atmospheric chemistry-climate modelling, there is evidence to suggest that monoterpene emissions from many plant species represent a combination of direct and stored emissions (Staudt et al., 1997; Kesselmeier and Staudt, 1999; Niinemets et al., 2004). As monoterpenes share a common synthesis pathway with isoprene, direct emissions of certain monoterpenes are dependent on light as well as temperature (Kesselmeier and Staudt, 1999; Lichtenthaler, 1999). In absence of direct evidence, such as that provided by light-dark transition experiments, the light-independent (Tingey et al., 1980; Guenther et al., 1991) and light-dependent algorithms (Guenther et al., 1993; Guenther, 1997; Staudt et al., 1997) were both therefore calculated for the potential EC of all terpenoid emissions.

Based on the concentration of each VOC calculated by GC-MS/FID and the air sampling flow rate, a rate of emission, $F_{i}\left(\mu \mathrm{gC} \mathrm{g}^{-1} \mathrm{~h}^{-1}\right)$, for each VOC species $i$ was calculated using Equation (1) (Ortega and Helmig, 2008):

$F_{i}=\frac{Q\left|C_{i o u t}-C_{i e m p t y}\right|}{M_{d r y}}$

where $C_{i_{\text {out }}}$ is the concentration of VOC species $i\left(\mu \mathrm{gC} \mathrm{mol}{ }^{-1}\right)$ in air exiting the enclosure containing a Cannabis spp. plant, $C_{\text {iempty }}$ is the concentration of VOC species $i\left(\mu \mathrm{gC} \mathrm{mol}{ }^{-1}\right)$ in air exiting the enclosure containing only the empty pot with soil and water, $M_{d r y}$ is the dry mass of leaves $(\mathrm{g})$, and $Q$ is the flow rate of air into the enclosure system (about $5.44 \mathrm{~mol} \mathrm{~h}^{-1}$ ). Calculated values of $F_{i}$ therefore represent emission rates at measured temperatures and PAR.

The emission capacity $\left(\varepsilon_{i}\right)$ for VOC $i$ was calculated following Guenther et al. (1995):

$\varepsilon_{i}=F_{i} / \gamma$

where $\varepsilon_{i}$ is the emission capacity at $T_{S}=30^{\circ} \mathrm{C}\left(\mu \mathrm{gC} \mathrm{g}{ }^{-1} \mathrm{~h}^{-1}\right), \mathrm{Fi}$ is the emission rate of the VOC $i\left(\mu \mathrm{gC} g\right.$ (dry matter) ${ }^{-1} \mathrm{~h}^{-1}$ ) calculated using Equation (1), and $\gamma$ is a dimensionless activity factor which corrects for temperature and light conditions. In equation (3), $\gamma$ is defined for temperature and independent of light.

$\gamma=\exp \left[\beta\left(T-T_{S}\right)\right]$

where $\beta$ is an empirical coefficient (in $\mathrm{K}^{-1}$ ) taken as $\beta=0.09$ for all monoterpenes, eucalyptol, and sesquiterpenes (Guenther et al., 1991; Ortega and Helmig, 2008; Ortega et al., 2008).

In equation (4), the $\gamma$ is a factor with a light dependent condition
(Guenther et al., 1993; Guenther, 1997; Staudt et al., 1997).

$\gamma=\left[\frac{\alpha C_{L 1} L}{\sqrt{1+\alpha^{2} L^{2}}}\right]\left[\frac{\exp \left(\frac{C_{T 1}\left(T-T_{S}\right)}{R T_{S} T}\right)}{C_{T 3}+\exp \left(\frac{C_{T 2}\left(T-T_{M}\right)}{R T_{S} T}\right)}\right]$

where $L$ is the photosynthetically active radiation (PAR, $\mu \mathrm{mol} \mathrm{m} \mathrm{m}^{-2}$ $\left.\mathrm{s}^{-1}\right), R$ is the ideal gas constant $\left(8.314 \mathrm{~J} . \mathrm{K}^{-1} \mathrm{~mol}^{-1}\right) . \alpha(=0.0027), C_{L 1}$ $(=1.066), \quad C_{T 1} \quad\left(=95,000 \mathrm{~J} \mathrm{~mol}^{-1}\right), \quad C_{T 2} \quad\left(=230,000 \mathrm{~J} \mathrm{~mol}^{-1}\right), C_{T 3}$ $(=0.961)$ and $T_{M}\left(=41^{\circ} \mathrm{C}\right)$ are empirical coefficients.

\section{Results}

The terpene emission rates per plant $\left(\mu \mathrm{gC} \mathrm{h}{ }^{-1}\right)$ and the percentage composition of the different emitted terpenes were calculated at 30 and 46 days of growth for all four Cannabis spp. strains with and without a light dependency. When a light-dependency was applied to plants at 46 days of growth, we estimated an increase of $5-10 \%$ in the emission rate. Given the high level of uncertainty in our rate estimate, the lower values without a light dependency are described in the following results. All estimates using a light dependency can be found in table S1A and S1B. Fig. 1 shows the measured composition and estimated terpene emission rates. These values are not normalized by leaf weight since the foliage was kept intact until 46 days of growth. $\beta$-myrcene and eucalyptol are the most abundant BVOC species at these two growth stages in all four strains, although the composition of terpene emissions varies among the growth stages and strains (Fig. 1). In each strain, the whole-plant emission increased as the plants grew bigger, which is to be expected due to the increased amount of foliage between 30 and 46 days. Critical Mass had the highest emission rate at both 30- and 46-day growth stages with $1.4 \mu \mathrm{gC} \mathrm{h} \mathrm{h}^{-1}$ and $8.6 \mu g \mathrm{Ch}^{-1}$ per plant. The terpenoid composition of Critical Mass emissions also changed across the different growth stages, at 30 days of growth the terpenoids with the highest emission rates were $\beta$-myrcene (43\%), and eucalyptol (19\%). Sixteen days later the largest emitted species were eucalyptol (32\%), $\beta$ myrcene $(18 \%)$ and $\gamma$-terpinene (14\%). For Lemon Wheel, eucalyptol (33\%, 38\%) and $\beta$-myrcene $(27 \%, 26 \%)$ were the dominant emissions. For Elephant Purple and Rockstar Kush the highest emissions were from $\beta$-myrcene (39\% and $41 \%$ ), eucalyptol (25\% and $28 \%$ ), and d-limonene $(17 \%$ and $8 \%)$ at 30 days. At 46 days Elephant Purple and Rockstar Kush had increases in $\gamma$-terpinene (8\%) and caryophyllene (5\% and 7\%) emissions.

After 46 days of growth, the ECs of three different strains were calculated at $30^{\circ} \mathrm{C}$ and normalized by dry leaf weight (Fig. 2A). These were calculated using GC-FID data unless there was a co-elution effect and the GC-MS signal was used as shown in Table S1. Dry leaf mass was not measured for Elephant Purple, hence EC could not be calculated for this strain. The highest total terpene EC (including monoterpenes, eucalyptol and caryophyllene) was $8.7 \pm 0.7 \mu \mathrm{gC} \mathrm{g}^{-1} \mathrm{hr}^{-1}$ for the Critical Mass strain, of which $5.7 \pm 0.5 \mu \mathrm{gC} \mathrm{g} \mathrm{g}^{-1} \mathrm{hr}^{-1}$ (66\%) was monoterpenes, $2.8 \pm 0.19 \mu \mathrm{gC} \mathrm{g}^{-1} \mathrm{hr}^{-1}(32 \%)$ was eucalyptol, and $0.2 \pm 0.01 \mu g \mathrm{~g} \mathrm{~g}^{-1} \mathrm{hr}^{-1}(2 \%)$ was caryophyllene. Total terpene EC for Lemon Wheel and Rockstar Kush were $5.9 \mu \mathrm{gC} \mathrm{g} \mathrm{g}^{-1} \mathrm{hr}^{-1}$ and $4.9 \mu \mathrm{gC}$ $\mathrm{g}^{-1} \mathrm{hr}^{-1}$. For Lemon Wheel, eucalyptol contributed $2.2 \mu \mathrm{gC} \mathrm{g}^{-1} \mathrm{hr}^{-1}$ (38\%) and monoterpenes $3.5 \mu \mathrm{gC} \mathrm{g}^{-1} \mathrm{hr}^{-1}$ (59\%); whereas for Rockstar Kush, the contributions were $0.8 \mu \mathrm{gC} \mathrm{g}^{-1} \mathrm{hr}^{-1}$ (17\%) and $3.7 \mu \mathrm{gC}$ $\mathrm{g}^{-1} \mathrm{hr}^{-1}(76 \%)$. The complete emission capacities of all terpene species, based using both the GC-FID and GC-MS data, are shown for all strains in Figure S1.

The emission variations of each terpene species among the three different Cannabis spp. strains after 46 days of growth are illustrated in Fig. 2B, which shows the mean for each species and ranges displayed as standard deviations. The primary emissions from Cannabis spp. are monoterpenes (ranging between 3.1 and $5.5 \mu \mathrm{gC} \mathrm{g}^{-1} \mathrm{hr}^{-1}$ ) and eucalyptol (1.0-3.0 $\mu \mathrm{gC} \mathrm{g}^{-1} \mathrm{hr}^{-1}$ ). The absolute value and range of caryophyllene emission capacities are much smaller at $0.18-0.3 \mu \mathrm{gC} \mathrm{g}{ }^{-1}$ 
A

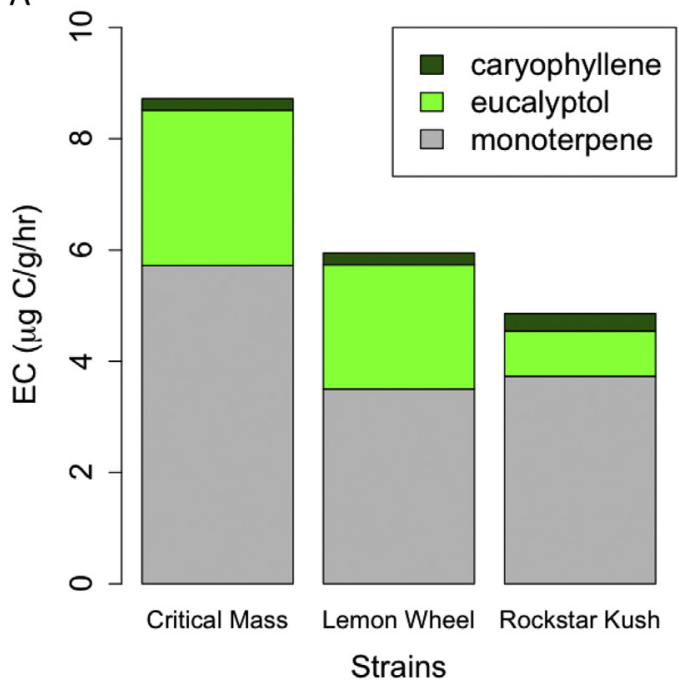

B

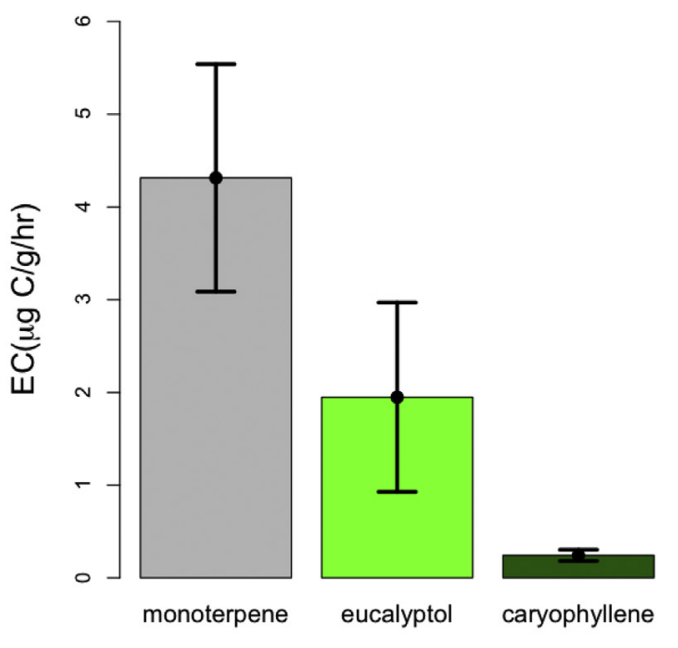

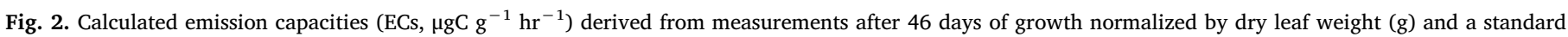

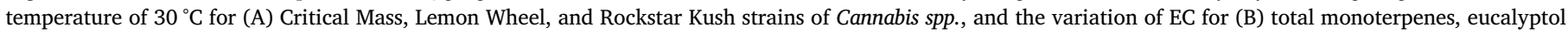

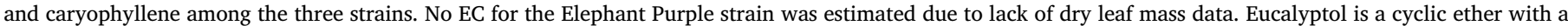

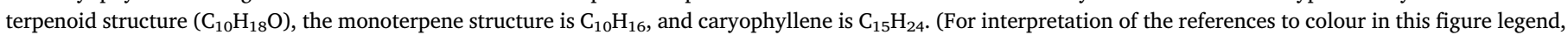
the reader is referred to the Web version of this article.)

$\mathrm{hr}^{-1}$.

To understand the potential impact of these emissions on air quality, the Ozone Formation Potential (OFP) in $\mu \mathrm{g}$ ozone per gram dry weight of Cannabis spp. per hour of each terpene was calculated as shown in Equation (5) (Ou et al., 2015):

OFP = Emission capacity $(\mu g / g / h r) \times M I R(o z o n e(g) / V O C(g))$

where MIR is the Maximum Incremental Reactivity (CARB, 2010) defined as the maximum number of grams of ozone produced per gram of reactant VOC. For this study, if a specific MIR is not available, the reported average monoterpene MIR (4.04 ozone $(\mathrm{g}) / \mathrm{VOC}(\mathrm{g})$ ) was applied to calculate OFPs. A surrogate MIR for a C15 alkene was used for caryophyllene, due to it having the same carbon number and being a similar alkene species.

Fig. 3A shows the OFP estimated for the individual terpenes emitted from three Cannabis spp. strains (Critical Mass, Lemon Wheel, and Rockstar Kush). The total OFP rate of Critical Mass is $41 \mu \mathrm{g} \mathrm{g}^{-1} \mathrm{hr}^{-1}$, Lemon Wheel is $27 \mu \mathrm{g} \mathrm{g}^{-1} \mathrm{hr}^{-1}$ and Rockstar Kush is $22 \mu \mathrm{g} \mathrm{g}^{-1} \mathrm{hr}^{-1}$. For Critical Mass and Lemon Wheel, the eucalyptol and $\beta$-myrcene species make up $50 \%$ of the total OFP rate. The OFPs of Critical Mass for eucalyptol and $\beta$-myrcene are $12.8 \mu \mathrm{gg}^{-1} \mathrm{hr}^{-1}$ and $7.3 \mu \mathrm{gg}^{-1} \mathrm{hr}^{-1}$. The OFPs of Lemon Wheel for eucalyptol and $\beta$-myrcene are $10.2 \mu \mathrm{g} \mathrm{g}^{-1} \mathrm{hr}^{-1}$ and $7.1 \mu \mathrm{g} \mathrm{g}^{-1} \mathrm{hr}^{-1}$. Rockstar Kush has a higher $\beta$ myrcene OFP rate, which is $9.7 \mu \mathrm{gg}^{-1} \mathrm{hr}^{-1}$, and eucalyptol is $3.7 \mu \mathrm{g} \mathrm{g}^{-1} \mathrm{~h}^{-1}$.

Fig. 3B shows the SOA formation potentials (SFPs) based on the (SOA) yield (Lee et al., 2006; Iinuma et al., 2009; Fry et al., 2014; Slade et al., 2017) of individual terpenes as calculate from Equation (6).

$S F P=$ Emission capacity $(\mu g / g / h r) \times S O A$ Yield

Fig. 3B estimated the SOA formation potential from the terpene species emitted from Critical Mass, Lemon Wheel and Rockstar Kush after 46 days of growth. For compounds without a published SOA yield (marked: \#), we assumed an SOA yield 0.3. The total SFP of Critical Mass is about $2.4 \mu \mathrm{gg}^{-1} \mathrm{hr}^{-1}$; with eucalyptol generating $0.63 \mu \mathrm{gg}^{-1}$ $\mathrm{hr}^{-1}$ of SOA, and $\gamma$-terpinene $0.4 \mu \mathrm{gg}^{-1} \mathrm{hr}^{-1}$ of SOA. For Lemon Wheel, the total SFP is $1.6 \mu \mathrm{g} \mathrm{g}^{-1} \mathrm{hr}^{-1}$, with eucalyptol contributing $0.51 \mu \mathrm{g} \mathrm{g}^{-1} \mathrm{hr}^{-1}$, $\beta$-myrcene is $0.19 \mu \mathrm{gg}^{-1} \mathrm{hr}^{-1}$ and d-limonene is $0.19 \mu \mathrm{g} \mathrm{g}^{-1} \mathrm{hr}^{-1}$. For Rockstar Kush, the total SFP is $1.3 \mu \mathrm{g} \mathrm{g}^{-1} \mathrm{hr}^{-1}$, with $0.26 \mu \mathrm{g} \mathrm{g}^{-1} \mathrm{hr}^{-1}$ from $\beta$-myrcene, and $0.27 \mu \mathrm{g} \mathrm{g}^{-1} \mathrm{hr}^{-1}$ from $\mathrm{d}$ limonene. Eucalyptol, $\gamma$-terpinene, and d-limonene have the largest SOA yields, but emissions were low for the strains tested here. The complete numbers of OFP and SFP of all terpenes for all strains are in supplemental table S4.

\section{Discussion and conclusion}

This study presents the first enclosure measurements of VOC emission rates from four commercial Cannabis spp. strains. This is a limited data set given the number of available strains and possible growing conditions. These measurements do, however, offer a good first step of demonstrating the potential impacts of emission from this new industry and provide constraints over possible ranges of emission rates. The results show that the magnitude of the emission rates from Cannabis spp., and the composition of the terpenes emitted, vary by strain and growing stage. These emitted terpenes also differ from other biogenic emissions from plant species normally found in Colorado. For example, the abundance of Pinus spp. in the region results in $\alpha$-pinene and $\beta$ pinene being the dominant terpene emissions with comparable amounts of 2-methyl-3-buten-2-ol (Harley et al., 1998). Terpene emissions from all our Cannabis spp. strains had eucalyptol and $\beta$-myrcene as the highest emitted species. Ross et al. (Ross and ElSohly, 1996) also found that fresh buds of Cannabis spp. plants were about $67 \% \beta$-myrcene. Similar to our results, Fischedick et al., (2010) (Fischedick et al., 2010) found that terpenes extracted from buds had different compositions across 11 strains. In six of these strains the dominant terpene was also $\beta$-myrcene ( $>35 \%)$.

It is important to note that for large-scale Cannabis spp. cultivation facilities the growth conditions are optimized. This includes elevating $\mathrm{CO}_{2}$ concentrations to $1500 \mathrm{ppm}$ in growing rooms, carefully managing water use, elevating light to $>1000 \mu \mathrm{mol} \mathrm{m}^{-2} \mathrm{~s}^{-1}$ (PAR), and maintaining temperatures greater than $30^{\circ} \mathrm{C}$. Further, these growers routinely use pesticides and fertilizer to optimize plant growth (Mills, 2012; Bauer et al., 2015; Ashworth and Vizuete, 2017). In these experiments plants were not grown at these ideal conditions, and thus the emissions measured here should be seen as a conservative estimate of the total amount of VOCs emitted from commercial facilities. Further, this study was also limited in the number strains that were analysed. Four strains of Cannabis spp. were measured in this study, however, there are a 

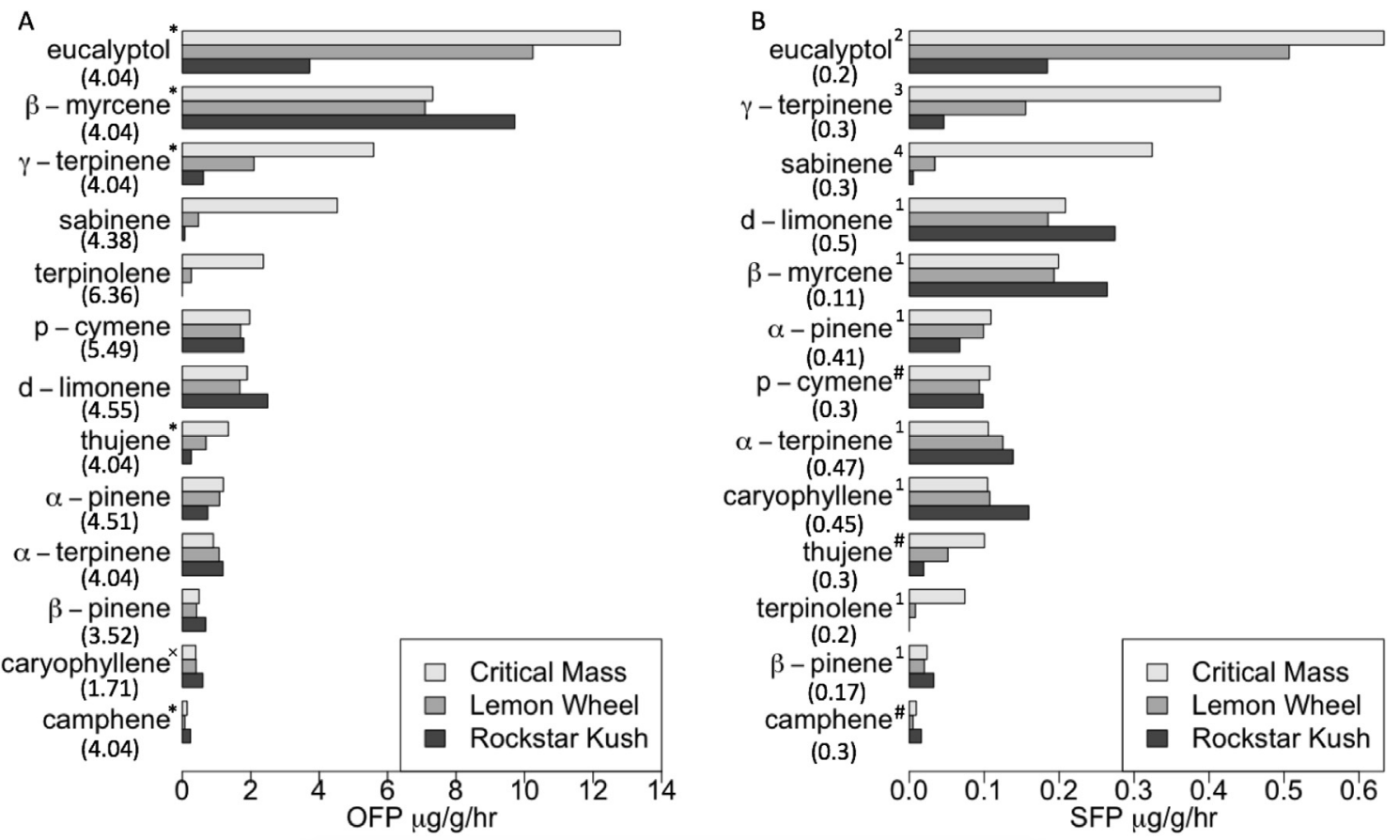

\footnotetext{
* Used monoterpene MIR $=4.04$

$\times$ Used $15 \mathrm{C}$-alkene MIR $=1.71$

\# compounds without a published SOA yield, assumed to be 0.3
}

Fig. 3. For the Critical Mass, Lemon Wheel, and Rockstar Kush strains, after 46 days of growth, the (A) The Ozone Formation Potential (OFP) rate estimated using the Maximum Incremental Reactivity (MIR) ratio (CARB, 2010) and (B) estimated SOA Formation Potential (SFP) based on published SOA yields [ ${ }^{1}$ (Lee et al., 2006), ${ }^{2}$ (Iinuma et al., 2009), ${ }^{3}$ (Slade et al., 2017), and ${ }^{4}$ (Fry et al., 2014)].

reported 620 Cannabis spp. strains planted in Denver cultivation facilities (Leafly, 2018). Those strains in CCF could change over time based on both consumer demand and other market factors. To constrain such uncertainties, further studies are required with a greater number of strains, a wider range of treatments focusing on light and temperature dependencies, controlled growing environments, and data that includes rates of venting to the atmosphere. As far as possible, conditions should reflect current industry practices so that a representative dataset of Cannabis spp. emission capacities could be built for the whole lifecycle of Cannabis spp. Such a dataset would enable authorities to assess the potential impacts of this new industry on regional air quality and if necessary determine mitigation strategies.

According to the Colorado Department of Revenue (CDOR, 2017), there were more than 1400 CCFs in Colorado in 2017, with over 600 in the Denver metro area. If these emissions from these cultivations are released into the ambient atmosphere they have the potential to impact local ozone and particulate matter (PM). For example, if each of the 600 facilities in Denver contained the permitted 10,000 plants (CDOR, 2017), with an assumed biomass of $1 \mathrm{~kg}$ /plant (Green, 2009; Jankauskiene and Gruzdeviene, 2015), and all emissions were released into the atmosphere, a EC of $8.7 \mu \mathrm{gC} \mathrm{g}^{-1} \mathrm{hr}^{-1}$ emission capacity would result in the annual total terpene emission of 520 metric ton year ${ }^{-1}$. This emission rate is more than twice that of the 250 metric ton year $^{-1}$ of total biogenic VOC emissions for Denver as estimated by the Western Air Quality Study (WAQS, 2017) for Colorado's 2008 regulatory air quality model simulations (RAQC, 2016). Using MIR values shown in Fig. 3 these BVOC emissions could produce 2100 metric ton year ${ }^{-1}$ of ozone, and using the yields shown in Fig. 3 produce 131 metric ton year $^{-1}$ of PM. Given the location of the VOCs emitted from Cannabis spp. from facilities in downtown Denver near major urban anthropogenic sources, there is the potential for the emissions from the commercial cultivation of Cannabis spp. to impact regional concentrations of ozone and PM. Additional work is needed to assess these potential air quality impacts in air quality model evaluations of not only Colorado, but in other states where the commercial cultivation and sale of Cannabis spp. has been legalized.

\section{Acknowledgments}

We would like to thank the National Center for Atmospheric Research, United States, Advanced Study Program (ASP) for their support and the Atmospheric Chemistry Observations and Modeling (ACOM) Laboratory for supplying the adsorbent cartridges, sampling equipment and analysis using GC-MS/-FID. NCAR's involvement in this study was limited to the measurement of emissions and their impact on air quality from the cultivation of cannabis and did not involve the manufacture, import, possession, use or distribution of cannabis. The National Center for Atmospheric Research is sponsored by the National Science Foundation, United States. Any opinions, findings and conclusions or recommendations expressed in this material do not necessarily reflect the views of the National Science Foundation. We also thank Dr. Feng-Chi Hsu, Dr. Jason Surratt, Ling Chun Yeh, and Grant Josenhans for their invaluable assistance.

\section{Appendix A. Supplementary data}

Supplementary data to this article can be found online at https:// doi.org/10.1016/j.atmosenv.2018.10.049.

\section{References}

Ashton, C.H., 2001. Pharmacology and effects of cannabis: a brief review. Br. J. Psychiatry 178, 101-106. https://doi.org/10.1192/bjp.178.2.101.

Ashworth, K., Vizuete, W., 2017. High time to assess the environmental impacts of cannabis cultivation. Environ. Sci. Technol. 51 (5), 2531-2533. https://doi.org/10. 
1021/acs.est.6b06343

Bauer, S., Olson, J., Cockrill, A., van Hattem, M., Miller, L., Tauzer, M., Leppig, G., 2015. Impacts of surface water diversions for marijuana cultivation on aquatic habitat in four northwestern California watersheds. PloS One 10 (3), 25. https://doi.org/10. 1371/journal.pone.0120016.

Braure, T., Bedjanian, Y., Romanias, M.N., Morin, J., Riffault, V., Tomas, A., Coddeville, P., 2014. Experimental study of the reactions of limonene with $\mathrm{OH}$ and OD radicals: kinetics and products. J. Phys. Chem. 118 (40), 9482-9490. https://doi.org/10. 1021/jp507180g.

CARB, California Air Resources Board, 2010. FINAL regulation order tables of maximum incremental reactivity (MIR) values. Retrieved from. https://www.arb.ca.gov/ consprod/regs/2012/4mirtable50411.pdf.

CDOR, Colorado Department of Revenue, 2017. Licensees - marijuana enforcement division. Retrieved from. https://www.colorado.gov/pacific/enforcement/licenseesmarijuana-enforcement-division.

D. E. A. US Department of Justice, 2017. Drugs of Abuse- a DEA Resource Guide.

Fehsenfeld, F., Calvert, J., Fall, R., Goldan, P., Guenther, A.B., Hewitt, C.N., Zimmerman, P., 1992. Emissions of volatile organic compounds from vegetation and the implications for atmospheric chemistry. Global Biogeochem. Cycles 6 (4), 389-430. https://doi.org/10.1029/91gb02965.

Fischedick, J.T., Hazekamp, A., Erkelens, T., Choi, Y.H., Verpoorte, R., 2010. Metabolic fingerprinting of Cannabis sativa L, cannabinoids and terpenoids for chemotaxonomic and drug standardization purposes. Phytochemistry 71 (17-18), 2058-2073. https://doi.org/10.1016/j.phytochem.2010.10.001.

Fry, J.L., Draper, D.C., Barsanti, K.C., Smith, J.N., Ortega, J., Winkler, P.M., ... Lee, L., 2014. Secondary organic aerosol formation and organic nitrate yield from NO3 oxidation of biogenic hydrocarbons. Environ. Sci. Technol. 48 (20), 11944-11953. https://doi.org/10.1021/es502204x.

Funk, J.L., Jones, C.G., Baker, C.J., Fuller, H.M., Giardina, C.P., Lerdau, M.T., 2003. Diurnal variation in the basal emission rate of isoprene. Ecol. Appl. 13 (1), 269-278. https://doi.org/10.1890/1051-0761(2003)013[0269:dvitbe]2.0.co;2.

Green, G., 2009. Cannabis Grow Bible: the Definitive Guide to Growing Marijuana for Recreational and Medical Use.

Guenther, A., 1997. Seasonal and spatial variations in natural volatile organic compound emissions. Ecol. Appl. 7 (1), 34-45. https://doi.org/10.2307/2269405.

Guenther, A., Hewitt, C.N., Erickson, D., Fall, R., Geron, C., Graedel, T., Zimmerman, P., 1995. A global-model of natural volatile organic-compound emissions. J. Geophys. Res.-Atmos. 100 (D5), 8873-8892. https://doi.org/10.1029/94jd02950.

Guenther, A., Monson, R.K., Fall, R., 1991. Isoprene and monoterpene emission rate variability - Observations with Eucalyptus and emission rate algorithm development. Journal of Geophysical Research-Atmospheres 96 (D6), 10799-10808. https://doi. org/10.1029/91jd00960.

Guenther, A., Zimmerman, P.R., Harley, P.C., Monson, R.K., Fall, R., 1993. Isoprene and monoterpene emission rate variability - model evaluations and sensitivity analyses. Journal of Geophysical Research-Atmospheres 98 (D7), 12609-12617. https://doi. org/10.1029/93jd00527.

Harley, P., Fridd-Stroud, V., Greenberg, J., Guenther, A., Vasconcellos, P., 1998. Emission of 2-methyl-3-buten-2-ol by pines: a potentially large natural source of reactive carbon to the atmosphere. Journal of Geophysical Research-Atmospheres 103 (D19), 25479-25486. https://doi.org/10.1029/98jd00820.

Harley, P., Eller, A., Guenther, A., Monson, R.K., 2014. Observations and models of emissions of volatile terpenoid compounds from needles of ponderosa pine trees growing in situ: control by light, temperature and stomatal conductance. Oecologia 176 (1), 35-55. https://doi.org/10.1007/s00442-014-3008-5.

Hillig, K.W., 2004. A chemotaxonomic analysis of terpenoid variation in Cannabis. Biochem. Syst. Ecol. 32 (10), 875-891. https://doi.org/10.1016/j.bse.2004.04.004.

Hites, R.A., Turner, A.M., 2009. Rate constants for the gas-phase beta-myrcene plus $\mathrm{OH}$ and isoprene plus $\mathrm{OH}$ reactions as a function of temperature. Int. J. Chem. Kinet. 41 (6), 407-413. https://doi.org/10.1002/kin.20413.

Hood, L.V.S., Dames, M.E., Barry, G.T., 1973. Headspace volatiles of marijuana. Nature 242, 402-403.

Iinuma, Y., Boge, O., Keywood, M., Gnauk, T., Herrmann, H., 2009. Diaterebic acid acetate and diaterpenylic acid acetate: atmospheric tracers for secondary organic aerosol formation from 1,8-cineole oxidation. Environ. Sci. Technol. 43 (2), 280-285. https://doi.org/10.1021/es802141v.

Jankauskiene, Z., Gruzdeviene, E., 2015. Screening of industrial hemp (cannabis sativa L.) cultivars for biomass yielding capacities in Lithuania. J. Nat. Fibers 12 (4), 368-377. https://doi.org/10.1080/15440478.2014.929556.

Kanakidou, M., Seinfeld, J.H., Pandis, S.N., Barnes, I., Dentener, F.J., Facchini, M.C., Wilson, J., 2005. Organic aerosol and global climate modelling: a review. Atmos. Chem. Phys. 5, 1053-1123.

Kesselmeier, J., Staudt, M., 1999. Biogenic volatile organic compounds (VOC): an overview on emission, physiology and ecology. J. Atmos. Chem. 33 (1), 23-88. https:// doi.org/10.1023/a:1006127516791.

Leafly, 2018. Cannabis Strain Explorer. Retrieved from. https://www.leafly.com/ explore/sort-alpha.

Lee, A., Goldstein, A.H., Keywood, M.D., Gao, S., Varutbangkul, V., Bahreini, R., Seinfeld, J.H., 2006. Gas-phase products and secondary aerosol yields from the ozonolysis of ten different terpenes. Journal of Geophysical Research-Atmospheres 111 (D7), 18. https://doi.org/10.1029/2005jd006437.
Lichtenthaler, H.K., 1999. The 1-deoxy-D-xylulose-5-phosphate pathway of isoprenoid biosynthesis in plants. Annu. Rev. Plant Physiol. Plant Mol. Biol. 50, 47-65. https:// doi.org/10.1146/annurev.arplant.50.1.47.

Madras, B.K., World Health Organisation, 2015. Update of cannabis and its medical use. Retrieved from. http://www.who.int/medicines/access/controlled-substances/6 2 cannabis update.pdf.

Marchini, M., Charvoz, C., Dujourdy, L., Baldovini, N., Filippi, J.J., 2014. Multidimensional analysis of cannabis volatile constituents: identification of 5,5-dimethyl-1-vinylbicyclo 2.1.1 hexane as a volatile marker of hashish, the resin of Cannabis sativa L. J. Chromatogr. A 1370, 200-215. https://doi.org/10.1016/j. chroma.2014.10.045.

Martyny, J.W., Serrano, K.A., Schaeffer, J.W., Van Dyke, M.V., 2013. Potential exposures associated with indoor marijuana growing operations. J. Occup. Environ. Hyg. 10 (11), 622-639. https://doi.org/10.1080/15459624.2013.831986.

Mills, E., 2012. The carbon footprint of indoor Cannabis production. Energy Pol. 46, 58-67. https://doi.org/10.1016/j.enpol.2012.03.023.

Niinemets, U., Loreto, F., Reichstein, M., 2004. Physiological and physicochemical controls on foliar volatile organic compound emissions. Trends Plant Sci. 9 (4), 180-186. https://doi.org/10.1016/j.tplants.2004.02.006

Ortega, J., Helmig, D., 2008. Approaches for quantifying reactive and low-volatility biogenic organic compound emissions by vegetation enclosure techniques - Part A. Chemosphere 72 (3), 343-364. https://doi.org/10.1016/j.chemosphere.2007.11. 020.

Ortega, J., Helmig, D., Daly, R.W., Tanner, D.M., Guenther, A.B., Herrick, J.D., 2008 Approaches for quantifying reactive and low-volatility biogenic organic compound emissions by vegetation enclosure techniques - Part B: Applications. Chemosphere 72 (3), 365-380. https://doi.org/10.1016/j.chemosphere.2008.02.054.

Ou, J., Zheng, J., Li, R., Huang, X., Zhong, Z., Zhong, L., Lin, H., 2015. Speciated OVOC and VOC emission inventories and their implications for reactivity-based ozone control strategy in the Pearl River Delta region, China. Sci. Total Environ. 530-531, 393-402. https://doi.org/10.1016/j.scitotenv.2015.05.062.

Pierce, T., Geron, C., Bender, L., Dennis, R., Tonnesen, G., Guenther, A., 1998. Influence of increased isoprene emissions on regional ozone modeling. Journal of Geophysical Research-Atmospheres 103 (D19), 25611-25629. https://doi.org/10.1029/ 98jd01804.

RAQC, Reginal Air Quality Council, 2016. State implementation plan for the 2008 8-hour ozone nationa ambient air quality standard. Retrieved from. https://raqc.egnyte. com/dl/q5zyuX9QC1/FinalModerateOzoneSIP_2016-11-29.pdf_.

Rice, S., Koziel, J.A., 2015. Characterizing the smell of marijuana by odor impact of volatile compounds: an application of simultaneous chemical and sensory analysis. PloS One 10 (12), 17. https://doi.org/10.1371/journal.pone.0144160.

Ross, S.A., ElSohly, M.A., 1996. The volatile oil composition of fresh and air-dried buds of Cannabis sativa. J. Nat. Prod. 59 (1), 49-51. https://doi.org/10.1021/np960004a.

Ryerson, T.B., Trainer, M., Holloway, J.S., Parrish, D.D., Huey, L.G., Sueper, D.T. Fehsenfeld, F.C., 2001. Observations of ozone formation in power plant plumes and implications for ozone control strategies. Science 292 (5517), 719-723. https://doi. org/10.1126/science.1058113.

Sakulyanontvittaya, T., Duhl, T., Wiedinmyer, C., Helmig, D., Matsunaga, S., Potosnak, M., Guenther, A., 2008. Monoterpene and sesquiterpene emission estimates for the United States. Environ. Sci. Technol. 42 (5), 1623-1629. https://doi.org/10.1021/ es702274e.

Slade, Jonathan H., de Perre, Chloé, Lee, Linda, Shepson, Paul B., 2017. Nitrate radical oxidation of gamma-terpinene: hydroxy nitrate, total organic nitrate, and secondary organic aerosol yields. Atmos. Chem. Phys. 17 (14), 8635-8650. https://doi.org/10. 5194/acp-17-8635-2017.

Staudt, M., Bertin, N., Hansen, U., Seufert, G., Ciccioli, P., Foster, P., Fugit, J.L., 1997. Seasonal and diurnal patterns of monoterpene emissions from Pinus pinea (L.) under field conditions. Atmos. Environ. 31, 145-156. https://doi.org/10.1016/s13522310(97)00081-2.

Tholl, D., Boland, W., Hansel, A., Loreto, F., Rose, U.S.R., Schnitzler, J.P., 2006. Practical approaches to plant volatile analysis. Plant J. 45 (4), 540-560. https://doi.org/10. 1111/j.1365-313X.2005.02612.x.

Tingey, D.T., Manning, M., Grothaus, L.C., Burns, W.F., 1980. Influence of light and temperature on monoterpene emission rates from slash pine. Plant Physiol. 65 (5), 797-801. https://doi.org/10.1104/pp.65.5.797.

Turner, C.E., Elsohly, M.A., Boeren, E.G., 1980. Constituents of cannabis-sativa 1.17. A review of the natural constituents. J. Nat. Prod. 43 (2), 169-234. https://doi.org/10. 1021/np50008a001.

UNGCDP, United Nations Global Commission on Drug Policy, 2014. Taking Control: Pathways to Drug Policies that Work. Retrieved from. https://www. globalcommissionondrugs.org/wp-content/uploads/2016/03/GCDP_2014_takingcontrol EN.pdf.

UNODC, United Nations Office on Drugs and Crime, 2016. World Drug Report 2016. Retrieved from. https://www.unodc.org/doc/wdr2016/WORLD_DRUG_REPORT 2016_web.pdf.

WAQS, Western Air Quality Study, 2017. IWDW-WAQS wiki. Retrieved from. http:// vibe.cira.colostate.edu/wiki.

WHO. World Health Organisation, 2016. The health and social effects of nonmedical cannabis use (ISBN 978924151024 0). Retrieved from. http://www.who.int/ substance_abuse/publications/msbcannabis.pdf. 